NBER WORKING PAPER SERIES

\title{
OBESITY AS A BARRIER TO THE \\ TRANSITION FROM WELFARE TO WORK
}

John Cawley

Sheldon Danziger

Working Paper 10508

http://www.nber.org/papers/w10508

\section{NATIONAL BUREAU OF ECONOMIC RESEARCH 1050 Massachusetts Avenue Cambridge, MA 02138}

May 2004

We thank Sarah Avellar, Douglas Besharov, Rachel Dunifon, and Harold Pollack and participants at the 2003 APPAM Fall Research Conference their helpful comments. Funds to collect and manage the Women's Employment Survey (WES) were provided by the Charles Stewart Mott Foundation, the Joyce Foundation, the John D. and Catherine T. MacArthur Foundation, the National Institute for Child Health and Development, and the National Institute of Mental Health (R24-MH51363). We thank George Kaplan for providing us with data on the measured weights and heights of WES respondents. We thank WES data manager Sarah K. Marsh for her assistance. The views expressed herein are those of the author(s) and not necessarily those of the National Bureau of Economic Research.

C2004 by John Cawley and Sheldon Danziger. All rights reserved. Short sections of text, not to exceed two paragraphs, may be quoted without explicit permission provided that full credit, including (C) notice, is given to the source. 
Obesity as a Barrier to the Transition from Welfare to Work

John Cawley and Sheldon Danziger

NBER Working Paper No. 10508

May 2004

JEL No. I3, J0, I1

\section{$\underline{\text { ABSTRACT }}$}

This paper utilizes a rich longitudinal data set -- the Women's Employment Study (WES) - to investigate whether obesity, which is common among women of low socioeconomic status, is a barrier to employment and earnings for current and former welfare recipients. We find evidence that, among current and former welfare recipients, high body weight is a greater barrier to labor market success for white women than for African-American women. Among white women, we consistently find a negative correlation between weight and labor market outcomes such as employment, hours worked, and earnings. Among African American women, weight is not correlated with employment, hours worked, or earnings, but it is correlated with the percentage of months spent on welfare between interviews. We provide suggestive evidence that these differences between white and African-American women in the relationship between body weight and labor market outcomes are partly due to differential weight-based discrimination in employment.

John Cawley

Department of Policy Analysis and Management

134 MVR Hall, Cornell University

Ithaca, NY 14853

and NBER

jhc38@cornell.edu

Sheldon Danziger

Gerald R. Ford School of Public Policy and

National Policy Center

Huron Annex, 1015 E. Huron

University of Michigan

Ann Arbor, MI 48109-1689

sheldond@umich.edu 


\section{Introduction}

In 1996, the Personal Responsibility and Work Opportunity Reconciliation Act (PRWORA) replaced the entitlement to Aid to Families with Dependent Children (AFDC) with block grants through Temporary Assistance for Needy Families (TANF). PRWORA required that at least 50 percent of all recipient families work or be in work preparation programs by the year 2002, and set a lifetime limit of 60 months of receipt of federal cash assistance, although states were allowed some flexibility in exempting individual cases from these requirements. As a result of welfare reform, expansions of the Earned Income Tax Credit, and increased federal and state funding of child care subsidies, cash welfare benefits to families with non-working parents fell dramatically after 1996, while public spending supporting working families increased dramatically (Blank, 2002).

Because PRWORA required most welfare recipients to seek employment, there is much policy interest in identifying barriers that reduce their probability of employment. Danziger et al. (2000) examine a variety of such barriers and document that a range of human capital, physical health, and mental health factors affect the probability that a single mother will satisfy TANF work requirements. Jayakody and Stauffer (2000) examine the effects of mental health barriers in particular. Corcoran, Danziger, and Tolman (2003) find that persistent physical health problems, mental health problems, and child health problems are associated with shorter employment spells among current and former welfare recipients.

One potential barrier to the employment of current and former welfare recipients that has not been previously studied is obesity. Among women in the U.S., the 
prevalence of obesity is above average for those of low socioeconomic status (Sobal and Stunkard, 1989). Obesity represents a potential barrier to labor market success because obese females tend to earn less than healthy-weight females; this relationship is stronger for white than African-American females (Averett and Korenman, 1999; Cawley, 2004). The recent and rapid rise in the prevalence of obesity in the U.S. - from 15 percent during 1976-1980 to 30.9 percent during 1999-2000 (Flegal et al., 2002) - makes it particularly important to understand how obesity affects the transition from welfare to work.

This paper utilizes unique panel data on a sample of current and former welfare recipients to answer the following questions: How do employment, earnings and the extent of welfare use vary with body weight? Do the correlations between obesity and labor market outcomes and between obesity and welfare use vary by race? Are these correlations explained by mental health or physical health?

We find a consistent correlation between weight and adverse labor market outcomes among white current and former welfare recipients, but, for most outcomes, a negligible correlation among African-American respondents. For white respondents, a 10 percent increase in weight in pounds from the sample mean is associated with a 12 percent decrease in the probability of current employment, an 8.9 percent decrease in the probability of full-time employment, 5.4 percent fewer hours worked per week, 5 percent fewer months worked between survey waves, a 16 percent increase in the percent of months spent on welfare between waves, and 10 percent lower earnings in the previous month. 
Among the African American respondents, weight is not significantly correlated with most labor market outcomes. However, a 10 percent increase in weight in pounds from the sample mean is associated with a 10.9 percent increase in the percent of months spent on welfare between survey waves. We conclude that while weight may be a barrier to employment for white current and former welfare recipients, among African American women weight appears to be largely uncorrelated with employment and earnings, though it may be a barrier to leaving welfare.

\section{Methods}

The goal of this paper is to generate consistent estimates of the relationship between weight and labor market outcomes and between weight and welfare use among current and former welfare recipients. We study a variety of outcomes: binary, skewed, and percentages. For binary outcomes (e.g. whether the respondent has a full-time job), we estimate logit models of the form:

$$
Y_{i t}=W_{i t} \beta+X_{i t} \gamma+\varepsilon_{i t}
$$

where $Y_{i t}$ represents the outcome $Y$ of woman $i$ at time $t$ and $W_{i t}$ represents her weight at time $t$. $X$ is a vector of variables that affect the outcome $Y$ (such as measures of human capital) and $\varepsilon$ is the residual, which we assume follows a logistic distribution.

For outcomes that are skewed (e.g. hours worked last week), we estimate semilog models of the form:

$$
\ln Y_{i t}=W_{i t} \beta+X_{i t} \gamma+\varepsilon_{i t}
$$

That is, we take the natural logarithm of the outcome and regress it on weight and the other regressors. Because the log transformation assigns no value when the variable is 
equal to zero, we take the natural logarithm of these variables after recoding earnings from $\$ 0$ to $\$ 1$ and hours worked from 0 to 1.

For outcomes that are percentages (e.g. percent of months worked) we use the logit transformation of the dependent variable and estimate models of the form:

$$
\ln \left(Y_{i t} /\left(1-Y_{i t}\right)\right)=W_{i t} \beta+X_{i t} \gamma+\varepsilon_{i t}
$$

Because the logit transformation assigns no value when the percent is equal to either zero or one, zero values were recoded as .001 and values of one were recoded as .999.

We estimate these models using pooled longitudinal data from two survey waves that included self-reports of weight. To address possible correlation over time in the error terms of each individual, we cluster-correct the standard errors. We estimate all models separately by race because there are differences in the ways that whites and African-Americans perceive their own weight (Stearns, 1997), and because previous studies have found significant differences across race in the correlations between weight and labor market outcomes (Averett and Korenman, 1996; Cawley, 2004).

\section{The Women's Employment Study (WES)}

The Women's Employment Study (WES) was designed to facilitate the analysis of the ways in which a variety of human capital, mental health, physical health, and family problems affect the ability of current and former welfare recipients to obtain and retain employment and make the transition from welfare to work. A key goal of the WES is to examine how the presence of such barriers affects the response of former recipients to new welfare program mandates. 
The initial sample consisted of 874 single mothers receiving cash welfare in February of 1997 . The sample was systematically drawn with equal probability from an ordered list of the universe of active single-mother cases of the Michigan Family Independence Agency. It is not a nationally representative sample; the sample was geographically limited to one urban county in Michigan, and cases were proportionately selected by zip code, age (18-54 years), and race (White non-Hispanic or AfricanAmerican non-Hispanic). We refer to these two groups as whites and AfricanAmericans; since there are no Hispanics in the WES sample, it will be taken for granted that both of these groups are non-Hispanic.

The data were collected in personal interviews conducted by trained interviewers through the Survey Research Center in the Institute for Social Research at the University of Michigan. Interviews for the first wave were conducted in Fall 1997. Wave 2 was conducted in Fall 1998, Wave 3 in Fall/Winter 1999, Wave 4 in Fall 2001, and Wave 5 in Fall 2003/Winter 2004. In each wave, attempts were made to contact respondents, but not non-respondents, to the previous wave. Response rates were 86 percent in wave 1 ( $N=753), 92$ percent in wave 2 ( $N=693), 91$ percent in wave $3(\mathrm{~N}=632)$ and 91 percent in wave 4. $(\mathrm{N}=577)$. There seems to be no systematic attrition in the sample, so observations are not weighted.

The WES is well-suited to studying obesity as a barrier to the transition from welfare to work. First, it contains a rich set of labor market outcomes and welfare use measures. We examine the following: an indicator variable for whether the respondent is not currently working, an indicator for current full-time employment, hours worked per 
week, percent of months worked since last interview, percent of months on welfare since last interview, and own earnings last month.

Second, the WES includes information on height and weight. In wave 3, respondents were asked to self-report their height in inches. In both waves 3 and 4, they were asked to self-report their weight in pounds. In this paper, models of the relationship between weight and labor market outcomes and weight and welfare use are estimated using data from waves 3 and 4.

Previous research has documented substantial reporting error in self-reports of weight (Rowland, 1998; Cawley, 2000). Reporting error may bias coefficient estimates (Bound, Brown, and Mathiowetz, 2002), so we correct for it using data on measured height and weight from a special health supplement to waves 3 and 4 of the WES. Only a subset of WES respondents participated in this supplement $(\mathrm{N}=299)$, so it is not possible to use measured weight for all respondents. The correlation involves using measured height and weight for the subset of WES respondents as validation data for the heights and weights reported by all respondents; details are provided in the Appendix.

Throughout this paper we use measures of weight and height that have been corrected for reporting error.

This paper uses two measures of body weight: weight in pounds and body mass index (BMI). BMI is calculated as weight in kilograms divided by height in meters squared. BMI is the standard measure of fatness in epidemiology and medicine (U.S. Department of Health and Human Services, 2001); it is used to classify individuals as overweight and obese by the U. S. National Institutes of Health (NIH), the World Health Organization, and the International Obesity Task Force (Flegal et al., 1998). 
Kaplan et al. (2003) compared the BMI of women in the WES health supplement to that of women of the same age and race in the National Health and Nutrition Examination Survey (NHANES) 1999-2000. They find that the mean BMI of WES respondents is 16 percent higher than that in the NHANES sample, which reflects the negative correlation between socio-economic status and obesity among women in the U.S.

We also experimented with a third measure of weight: the clinical weight classification, established by the NIH. According to this classification, a respondent whose $\mathrm{BMI}$ is below 18.5 is underweight, one whose $\mathrm{BMI}$ is at least 18.5 but less than 25 is healthy weight, one whose BMI is at least 25 but less than 30 is overweight and one whose BMI is 30 or higher is obese (U.S. National Institutes of Health, 1998; Epstein and Higgins, 1992). However, when we included indicator variables for underweight, overweight, and obese as our controls for weight, none of the three coefficients was statistically significant. We were concerned that the relatively small cell sizes (four weight classifications times two race groups) precluded accurate estimates of the coefficients, so we experimented with including just one indicator. Even then, whether the indicator was for overweight or obese, the coefficients associated were generally not statistically significant.

The distribution of weight is skewed further to the right for the AfricanAmericans in WES than the white respondents. Twenty-five percent of whites meet the clinical definition of healthy weight, compared to 15 percent of African-Americans. Forty-nine percent of white respondents, and 56 percent of African-Americans, are obese. Kaplan et al. (2003) find that the prevalence of obesity among white WES respondents is 
nearly twice as high as that among white female NHANES respondents of the same ages. In contrast, the prevalence of obesity among African-American WES respondents is only slightly higher than that among black female NHANES respondents of the same ages.

We control for height in inches when our regressor of interest is weight in pounds. It is not necessary to control for height when BMI is our regressor, as it is a measure of weight-for-height.

Summary statistics for the WES sample of whites appear in Table 1A, and those for African-Americans in Table 1B. A comparison of Tables 1A and 1B indicates that the two samples have different mean weights. The average weight of whites is 180.72 pounds, while that of African-Americans is 185.29 pounds.

While we do not use an indicator for obesity as a measure of weight, our study concerns obesity as a barrier to employment because the average woman in our sample is obese. The average BMI is 31.35 among whites and 32.16 among African-Americans. In this paper, we limit analysis to labor market and welfare use outcomes in waves 3 and 4, when weight was reported. However, at times we examine cumulative measures of labor market performance, such as the percent of months worked since the previous interview and the percent of months on welfare since the last interview. When we examine cumulative measures, we must assume that the individual's unobserved weight during the period between waves was equal to her self-reported weight.

We control in each regression for factors that affect labor market participation and performance, specifically: measures of human capital, demographic and personal characteristics, and child characteristics. We control for the following measures of human capital: indicator variables for no job market skills, low job market skills, less 
than a high school education, and more than a high school education. We control for the following demographic and personal characteristics: indicator variables for age category (18-24, 25-34, and 35-44, with the highest category, 45+, omitted), respondent is currently living with a husband or cohabiting with an unmarried partner, respondent never married, the respondent either has no car or no driver’s license, and respondent has a conviction for a crime other than a traffic offense. The child characteristics controlled for are: the number of children the respondent cares for, the number of children between the ages of 0 and 2 that the respondent cares for, and indicator variables for whether one of the respondent's children has a physical or mental health problem. We also include an indicator variable for year to capture differences in economic conditions between Fall 1999 when wave 3 was fielded and Fall 2001 when wave 4 was fielded.

After estimating our initial models, we seek to determine the extent to which weight is correlated with labor market outcomes and welfare use after controlling for the respondent's mental and physical health. The additional regressors added to the model are: an index of physical limitations (in which a higher score reflects better health), and indicator variables for whether the respondent meets the diagnostic screening criteria for major depression or other mental health problems (such as general anxiety disorder, social phobia, post-traumatic stress disorder, alcohol dependence and drug dependence), and whether the respondent rates her own health as fair or poor; see Danziger et al. 2000 for a detailed discussion of WES variables.

\section{Empirical Results}


We present in each table the coefficients, t statistics, and elasticities associated with the weight variables: either weight in pounds or BMI.

The first outcome examined is whether the respondent is working at the time of the interview. Table 2 indicates that white females who are heavier (whether measured in weight in pounds or BMI) are more likely to report that they are not currently working. Both coefficients are statistically significant at the 10 percent level. For white females, an increase in pounds of 10 percent from the mean is associated with a 12 percent increase in the probability of not working. In contrast, the coefficients on weight in pounds and BMI for African-Americans are not statistically significant.

The second outcome is whether the respondent is employed full-time at the time of the survey. Heavier white females are less likely to be employed full-time; the coefficients on both weight in pounds and BMI in Table 3 are statistically significant at the 5 percent level. For white females, an increase in pounds of 10 percent from the mean is associated with an 8.9 percent decrease in the probability of full-time employment. Weight is not correlated with the probability of full-time employment for African-American respondents.

Table 4 indicates that heavier white females tend to work fewer hours per week than lighter white females. The coefficients imply that, ceteris paribus, a 10 percent increase in pounds from the mean is associated with 5.4 percent fewer hours worked per week. Again, no significant correlation was found for African Americans.

We examined the percent of months worked since the last interview in Table 5. Heavier white females worked a smaller percentage of months between waves, whether weight is measured in pounds or BMI; both coefficients are significant at the 5 percent 
level. For white females, a 10 percent increase in pounds from the mean is associated with a 5 percent decrease in months worked between waves. ${ }^{1}$ Neither weight nor BMI is statistically significant for African-Americans. ${ }^{2}$

We also study the percent of months on welfare since the last interview; these results are presented in Table 6. For whites, a 10 percent increase in pounds is associated with a 16 percent increase in the percent of months spent on welfare between waves. Weight is also correlated with months on welfare for African-Americans; a 10 percent increase in pounds is associated with an 11 percent increase in the percent of months spent on welfare between waves. This is interesting for two reasons. First, the magnitude of the effect is large. Second, this finding is different from the pattern of the other outcomes: weight is not correlated with the probability of employment, the probability of full-time employment, hours worked, or months worked, for African American females. ${ }^{3}$

Finally, we examine the relationship between weight and own earnings last month in Table 7. Among whites, a 10 percent increase in weight from the mean is associated with

\footnotetext{
${ }^{1}$ In regressions in which the dependent variable is a percentage that has been logit transformed, the elasticity is calculated as: $\varepsilon=(1-\bar{Y}) \bar{W} \beta$ where $\bar{Y}$ is the average outcome of interest in the sample, $\bar{W}$ is the average weight in the sample, and $\beta$ is the coefficient on weight. For example, the elasticity of percent months worked since last interview with respect to weight in pounds for white females (see Table 5 for the coefficient and Table 1A for the means) is equal to

${ }^{2}$ The percent of months worked since the last interview includes former welfare recipients who have moved completely off the welfare rolls and into the labor force and "combiners," those who both work and receive cash welfare benefits. To study the former group in isolation, we also analyze the percent of months since the last interview that the respondent was wage reliant, defined as the months in which she earned wages and received no cash benefits. Consistent with the results in Table 5, we found that heavier white females spent fewer months wage reliant since the last interview. There was no statistically significant relationship for African-American females.

${ }^{3}$ The variable for percent of months spent on welfare includes both those who are not working at all and those who work some hours in the months in which cash benefits were received. To distinguish the former group, we examine the percent of months that the respondent was welfare reliant, defined as a month in which the respondent received cash welfare but did not have any wages. Consistent with the results in Table 6, both weight measures are statistically significant at the $10 \%$ level for both whites and AfricanAmericans.
} 
10 percent lower earnings. The correlation of weight with log earnings in the WES is larger than that of weight with log wages in the National Longitudinal Survey of Youth (NLSY); while a ten-pound increase in pounds among white females in the WES is associated with 5.5 percent lower earnings, a ten-pound increase in weight among white females in the NLSY is associated with 1.4 percent lower wages (Cawley, 2004). Part of the discrepancy in magnitudes is due to the WES results reflecting both the correlation of weight with wages and the correlation of weight with hours worked, whereas the NLSY results are simply for wages.

Using the method of instrumental variables, Cawley (2004) finds evidence that the relationship is causal; that is, weight lowers wages for white females. If that causal relationship exists in the WES as well, the relative results suggest that weight represents a greater barrier to earnings for white current or former welfare recipients than for the population of white females as a whole. The coefficient on weight in the log earnings regression is not statistically significant for African American women.

For convenience in comparing results across outcomes and groups, Table 8 presents the marginal effect or elasticity of each outcome with respect to weight in pounds and BMI for both white and African-American respondents. Consistently, outcomes are more elastic to weight for whites than for African-Americans.

Obesity is correlated with depression (Williamson and O’Neil, 1998), but that may be the result of obese individuals becoming depressed about their physical condition or the result of depression leading to increased calorie consumption. Obesity is also correlated with physical health, including diabetes mellitus, hypertension, stroke, gallbladder disease, cardiovascular disease, respiratory disease, cancer, arthritis, and gout (Pi-Sunyer, 
2002; Bray, Bouchard, and James, 1998). While some illness is caused by obesity, in other cases illness limits physical activity and contributes to obesity.

Because the extent to which mental and physical health are the causes or consequences of obesity is not clear, we did not control for them in the models discussed above. Now, to establish a lower bound on the correlation of weight with labor market and welfare use outcomes, we add to our set of regressors measures of mental and physical health. We first add variables that indicate whether the respondent meets diagnostic screening criteria for major depression and for other mental health problems measured in WES. ${ }^{4}$ Second, we add to the original model an indicator variable for whether self-reported health is fair or poor, and an index of physical health limitations. ${ }^{5}$ Third, we add both the mental health and the physical health controls to the original model.

Our results (not shown, available on request) are robust to the inclusion of the mental health variables. Point estimates of coefficients and t statistics fall, but the weight variables tend to retain their statistical significance for white females.

When we control for physical health (not shown, available on request), many weight coefficients are no longer statistically significant for whites; the exception is the weight coefficient for the outcome percent of months on welfare since the last interview, which remains significant and positive. For African Americans, some interesting results appear. Weight in pounds and BMI become statistically significant in the regressions for whether

\footnotetext{
${ }^{4}$ The correlation between weight in pounds and depression is .014, and that between BMI and depression is .006. The correlation between weight in pounds and the mental health problems variable is .015, and that for BMI and mental health problems is .022.

${ }^{5}$ The correlation between weight in pounds and self-reported health is .080 , and that between BMI and self-reported health is .094 . The correlation between weight in pounds and the physical limitations scale (on which a higher score is better health) is -.206, and that for BMI and the physical limitations scale is .217 .
} 
the respondent is not currently working and for hours worked per week. A surprising finding is that the coefficients have the opposite sign than those for whites: controlling for health, heavier African-American females are more likely to work, and tend to work longer hours, than lighter African-American females. These results suggest that there are two types of heavy African-American respondents: those with physical limitations that prevent them from working, and those without physical limitations who are likely to work (and to work long hours). If one does not control for physical limitations, then overall weight appears to have no correlation with labor market outcomes for African Americans.

When we add controls for both mental and physical health problems, most of the weight coefficients are no longer statistically significant. The only ones remaining significant are: for white females, weight in pounds and BMI in the regression for percent of months on welfare since last interview; for African-American females: weight in pounds in the regression for hours worked per week.

Overall, the addition of mental and physical health problems indicate that weight is correlated with both mental and physical health problems, but it is unclear in which direction the causal arrow points. Obesity may increase the likelihood of depression and physical limitations, and vice-versa.

\section{Discussion}

Welfare reform in the late 1990s created incentives for welfare recipients to work. In order to facilitate labor market participation for this population, it is necessary to know the barriers they face to employment. This research represents a step in that direction 
because it identifies a little-recognized barrier to employment and earnings for certain welfare recipients: obesity.

We consistently find a correlation between weight and adverse labor market outcomes among white respondents even in a modestly-sized sample. For white females, a 10 percent increase in weight from the mean is associated with a 12 percent decrease in the probability of current employment, an 8.9 percent decrease in the probability of fulltime employment, 5.4 percent fewer hours worked, 5 percent fewer months worked between survey waves, 16 percent more months spent on welfare between survey waves, and 10 percent lower earnings.

Among African American respondents, weight is only correlated with one outcome: welfare receipt. A 10 percent increase in weight in pounds is associated with a 10.9 percent increase in the percent of months spent on welfare between waves. It is intriguing that, for African-Americans, weight is not correlated with employment, fulltime employment, or hours, but it is correlated with months on welfare.

There exist three broad categories of explanations for our findings. The first is that obesity lowers wages and reduces employment; for example, by impairing health or because of workplace discrimination against heavier respondents. The second is that unemployment and/or low earnings cause obesity. This would be true if poorer people consume cheaper, more fattening, foods. The third category of explanations is that unobserved variables cause both obesity and impair labor market performance. A limitation of this paper is that we can only speculate on the causal relationship embedded in the correlations we observe. However, Cawley (2004), using the method of 
instrumental variables, finds a causal relationship between weight and lower wages for white, but not African-American, females.

The full policy implications of our findings depend on the underlying causal relationship. If obesity causes unemployment and low wages, one strategy for easing the transition from welfare to work may be to expand Medicaid to cover treatment for obesity, nutrition counseling, and weight loss treatments. Medicaid coverage of antiobesity pharmaceuticals and surgical treatments for obesity are determined on a state-bystate basis (American Obesity Association, 2002). To the extent that such treatments improve labor market outcomes and reduce welfare use, public savings may offset some of the cost of such expansions. Obviously, a cost-effectiveness analysis of expanded Medicaid coverage is beyond the scope of this paper.

It is not clear why our results differ so radically for whites and African-Americans. One possibility is that there exists employment discrimination on the basis of weight that is more punitive towards white than black females. Researchers have tested for weightbased discrimination in laboratory settings; participants are asked to make hiring or promotion decisions on the basis of materials that include photographs, videotapes, or descriptions indicating the worker's weight. The weights are manipulated to determine the extent to which hiring decisions are driven by discrimination against the obese. Reviews of this research (Roehling, 1999; Puhl and Brownell, 2001) document abundant evidence of weight-based discrimination at every stage of employment, from the hiring decision through wage-setting and promotion. Roehling (1999) found that weight explains a greater proportion of the variance in hiring decisions than even race or gender. A recent reflection of such sentiment is found in the 2003 Gallup Consumption Habits 
Survey, in which 20 percent of respondents answered that they would be less likely to hire a job applicant if they learned that the applicant was overweight (Gallup, 2003).

In an attempt to determine whether weight is correlated with labor market outcomes for white females as a result of workplace discrimination, we use a question that was asked of a subset of the WES sample: whether at their current or most recent job they were discriminated against because of their weight. ${ }^{6}$ Such discrimination is reported by 3.7 percent of overweight and obese white respondents and 1.6 percent of overweight and obese African-American respondents, a difference that is significant at the ten percent level. $^{7}$ This is consistent with the hypothesis that the difference between white and African-American females in the earlier results is due to differential weight-based employment discrimination.

Strauss and Pollack (2003) find in a sample of adolescents that being overweight is associated with a smaller social network of friends among white females but not AfricanAmerican females. If this is also true for adult women, and a network of friends fosters employment, then this may also help explain the pattern of results across race.

The sociological literature offers another possible explanation for the differences in results between whites and African Americans: obesity has a more adverse impact on the self-esteem of white females than on that of black females, who report perceiving higher weight as a signal of power and stability (Stearns, 1997). Averett and Korenman (1999) find that obesity is associated with lower self-esteem among white females, but not black

\footnotetext{
${ }^{6}$ For current workers, the wording of this wave 4 question is: "On your current main job, have you been discriminated against because your weight was too high or too low?” For non-workers, the question was worded: "On your most recent job, were you discriminated against because your weight was too high or too low?”

${ }^{7}$ If we limit our analysis to obese respondents, weight-based discrimination is reported by 5.0 percent of whites and 2.4 percent of African-Americans. The sample sizes are small (199 obese white and 292 obese African-American respondents), so although the point estimate of the difference in means is larger, the difference is only significant at the 12 percent level.
} 
females, but they also find that controlling for differences in self-esteem does not explain differences across race in the relationship between obesity and wages. Future research should pursue explanations for such dramatic differences across race in the correlation between weight and labor market outcomes. 


\section{Appendix: Correcting for Reporting Error in Weight and Height}

This appendix assesses the extent of reporting error in weight and height in the WES, and corrects for it. We use data on measured height and weight from a health supplement to waves 3 and 4 in which respondents were weighed and measured at a clinic or in their home by trained nurses. Only a subset of WES respondents ( $N=299)$ participated in this supplement, so it is not possible to use measured weight for all respondents. We use measured height and weight for the health supplement respondents as validation data for the heights and weights self-reported by all respondents.

Wave 3 interviews concluded in January 2000 and wave 4 interviews began in October 2001. The measurements of weight and height took place between June 2000 and May 2001. A limitation of the data is that the measurements did not take place on the same day as the interview; that would be ideal because the measurement would reflect the true value of weight at the time weight was self-reported. We compare measurements taken during calendar year 2000 with wave 3 self-reports, and measurements taken during calendar year 2001 with wave 4 self-reports.

A comparison of measured and self-reported weight among participants in the WES health supplement suggests that self-reports of weight likely contain error. The exact degree of reporting error cannot be determined, because the weight measurement and self-report did not occur on the same day, but large differences between the two measures are likely due to reporting error. The correlation between measured weight and self-reported weight is .90, and the correlation between measured height and self-reported height is .91. On average, WES respondents who participated in the health supplement underreported their weight by 9.9 pounds or 4.4 percent. There is no clear pattern of 
misreporting of weight by actual weight; underweight, healthy weight, overweight, and obese women all on average underreport their weight by roughly ten pounds. This is in contrast to previous studies, e.g. Rowland (1989), which have found in nationally representative samples that the degree of misreporting rises with actual weight.

We correct for reporting error using the method of Lee and Sepanski (1995) and Bound et al. (2002). Specifically, measured weight (height) was regressed on actual weight (height) for the participants in the health supplement. ${ }^{8}$ Based on the results of a Chow test, the validation regression for weight was estimated separately for white and African-American respondents, and the validation regression for height was estimated for whites and African-Americans pooled. Reported values were strong predictors of measured values; the $\mathrm{R}^{2}$ was .88 in the weight regression for whites, .77 in the weight regression for African-Americans, and .84 in the height regression for both groups pooled. Self-reported height and weight for all WES respondents are then multiplied by the coefficients on the reported values and the intercept is added, using the weight coefficient estimated using the appropriate race group. The fitted values of weight in pounds, height in inches, and BMI, corrected for reporting error, are used throughout the paper. All of the models reported have also been estimated using self-reported weight in pounds and BMI, with very similar results.

Appendix Table 1 lists the mean values of the weight and height variables both before and after the correction for reporting error. On average, the corrected weight is considerably higher than self-reported weight; this causes large changes in the percentages of respondents who fall into certain clinical weight classifications. For

\footnotetext{
${ }^{8}$ The reported value was the only regressor used in the weight and height regressions. We experimented with including measures of age, education, and reported value squared, but the coefficients were not statistically significant.
} 
whites, the average corrected weight is roughly twelve pounds greater than the average self-reported weight, while for African-Americans the average corrected weight is eight pounds higher than the average self-reported weight. The fraction of respondents who are classified as clinically underweight or healthy weight falls dramatically after the correction. There is little change in the percent of respondents classified as overweight, but there is a large increase in the percent classified as obese; an extra 13 percent of whites and an extra 14 percent of the African-Americans are newly classified as obese after the correction for reporting error. The means of reported and measured height are very similar; previous studies also found that self-reported and measured height are quite similar (Rowland, 1989). 


\section{Works Cited}

American Obesity Association. "Health Insurance Coverage.” World wide web content. 2002. http://www.obesity.org/treatment/health.shtml

Averett, Susan and Sanders Korenman. 1996. “The Economic Reality of the Beauty Myth.” Journal of Human Resources 31(2): 304-330.

Averett, Susan and Sanders Korenman. 1999. "Black-White Differences in Social and Economic Consequences of Obesity.” International Journal of Obesity. 23: 166173.

Blank, Rebecca M. 2002. “Evaluating Welfare Reform in the United States.” Journal of Economic Literature, XL(4): 1105-1166.

Bound, John, Charles Brown, and Nancy Mathiowetz. "Measurement Error in Survey Data.” in Handbook of Econometrics, volume 5, ed. James Heckman and Ed Leamer. New York: Springer-Verlag, 2002.

Bray, George A., Claude Bouchard, and W.P.T. James (editors). 1998. Handbook of Obesity. (Marcel Dekker: New York).

Cawley, John. 2000. “An Instrumental Variables Approach to Measuring the Effect of Obesity on Employment Disability.” Health Services Research 35(5): 1159-1179, 2000.

Cawley, John. 2004. “The Impact of Obesity on Wages.” Journal of Human Resources, 39(2): 452-474.

Corcoran, Mary, Sandra Danziger, and Richard Tolman. 2004. “Employment Duration of African-American and White Welfare Recipients and the Role of Persistent Health and Mental Health Problems." Women and Health, forthcoming.

Danziger, S. K., Corcoran, M., Danziger, S., Heflin, C., Kalil, A., Levine, J., Rosen, D., Seefeldt, K. S., Siefert, K., \& Tolman, R. 2000. "Barriers to the Employment of Welfare Recipients.” In R. Cherry \& W. Rodgers (Eds.) Prosperity for All? The Economic Boom and African Americans. New York: Russell Sage Foundation, pp. 239-272.

Epstein, Frederick H. and Millicent Higgins. 1992. “Epidemiology of Obesity.” In Obesity, eds. Per Bjorntorp and Bernard N. Brodoff, 230-342. New York: J. B. Lippincott Company.

Flegal, Katherine M., Margaret D. Carroll, Cynthia L. Ogden, and Clifford L. Johnson. 2002. "Prevalence and Trends in Obesity Among U.S. Adults, 1999-2000." JAMA. October 9. 288(14): 1723-1727.

Flegal, K. M., M. D. Carroll, R. J. Kuczmarski, and C. L. Johnson. 1998. “Overweight and Obesity in the United States: Prevalence and Trends, 1960-1994.” International Journal of Obesity 22: 39-47.

Gallup Organization. 2003. "Poll Analyses: Smoking Edges Out Obesity as Employment Liability.” August 7.

Jayakody, R., \& Stauffer, D. 2000. "Mental Health Problems Among Single Mothers: Implications For Work and Welfare Reform.” Journal of Social Issues, 54: 617634. 
Kaplan, George A. et al. 2003. "The Health of Poor Women Under Welfare Reform.” Unpublished manuscript, University of Michigan.

Lee, Lung-fei and Jungsywan H. Sepanski. 1995. "Estimation of Linear and Nonlinear Errors-in-Variables Models Using Validation Data.” Journal of the American Statistical Association 90(429): 130-40.

Nieto-Garcia, F. Javier, Trudy L. Bush, and Penelope M. Keyl. 1990. "Body Mass Definitions of Obesity: Sensitivity and Specificity Using Self-Reported Weight and Height.” Epidemiology, 1(2): 146-152.

Pi-Sunyer, F. Xavier. 2002. "Medical Complications of Obesity in Adults." In Fairburn, Christopher G. and Kelly D. Brownell, Eating Disorders and Obesity: A Comprehensive Handbook, $2^{\text {nd }}$ Edition. (Guilford Press: New York).

Puhl, Rebecca, and Kelly D. Brownell. 2001. "Bias, Discrimination, and Obesity.” Obesity Research, 9(12): 788-805.

Roehling, Mark V. 1999. "Weight-Based Discrimination in Employment: Psychological and Legal Aspects.” Personnel Psychology, 52(4): 969-1016.

Rowland, Michael L. 1989. "Reporting Bias in Height and Weight Data." Statistical Bulletin, 70(2): 2-11.

Sobal, Jeffery and Albert J. Stunkard. 1989. "Socioeconomic Status and Obesity: A Review of the Literature.” Psychological Bulletin, 105(2): 260-275.

Stearns, Peter N. 1997. Fat History: Bodies and Beauty in the Modern West. (New York: New York University Press).

Strauss, Richard S., and Harold A. Pollack. 2003. "Social Marginalization of Overweight Children.” Archives of Pediatric and Adolescent Medicine, 157: 746752.

U.S. Department of Health and Human Services. 2001. The Surgeon General's Call to Action to Prevent and Decrease Overweight and Obesity. Washington, DC: U. S. Government Printing Office.

U. S. National Institutes of Health, National Heart, Lung, and Blood Institute. 1998. Clinical Guidelines on the Identification, Evaluation, and Treatment of Overweight and Obesity in Adults. Washington, DC: National Institutes of Health, National Heart, Lung, and Blood Institute.

Williamson, Donald A. and Patrick Mahlen O’Neil. 1998. "Behavioral and Psychological Correlates of Obesity.” In Bray, George A., Claude Bouchard, and W.P.T. James (editors), Handbook of Obesity. (Marcel Dekker: New York).

Wolf, A. and Colditz, G. 1998. Current Estimates of the Economic Cost of Obesity in the United States. Obesity Research. March. 6: 97-106. 


\section{Table 1A: Summary Statistics for White Non-Hispanic Sample}

\begin{tabular}{|c|c|c|c|c|c|}
\hline \multirow[t]{2}{*}{ Variable } & \multicolumn{5}{|c|}{ Summary Statistics } \\
\hline & $\mathbf{N}$ & Mean & S.D. & Min & Max \\
\hline Indicator: not working & 527 & .33 & .47 & 0 & 1 \\
\hline Indicator: working full time & 527 & .42 & .49 & 0 & 1 \\
\hline Hours worked & 527 & 24.59 & 20.31 & 0 & 90 \\
\hline Own earnings last month (2001 \$) & 527 & 768.75 & 766.65 & 0 & 4252.10 \\
\hline $\begin{array}{l}\text { Percent of months worked since last } \\
\text { interview }\end{array}$ & 527 & .70 & .37 & 0 & 1 \\
\hline $\begin{array}{l}\text { Percent of months of wage reliance since } \\
\text { last interview }\end{array}$ & 527 & .56 & .40 & 0 & 1 \\
\hline $\begin{array}{l}\text { Percent of months on welfare since last } \\
\text { interview }\end{array}$ & 527 & .27 & .37 & 0 & 1 \\
\hline $\begin{array}{l}\text { Percent of months of welfare reliance } \\
\text { since last interview }\end{array}$ & 527 & .12 & .28 & 0 & 1 \\
\hline $\begin{array}{l}\text { Indicator: reports discrimination on basis } \\
\text { of weight at current / most recent job }\end{array}$ & 416 & .04 & .19 & 0 & 1 \\
\hline Weight in pounds & 527 & 180.72 & 54.48 & 87.79 & 440.02 \\
\hline Height in inches & 527 & 63.59 & 2.47 & 52.14 & 69.41 \\
\hline Body Mass Index & 527 & 31.35 & 8.98 & 15.73 & 67.54 \\
\hline Indicator: underweight & 527 & .02 & .14 & 0 & 1 \\
\hline Indicator: healthy weight & 527 & .25 & .44 & 0 & 1 \\
\hline Indicator: overweight & 527 & .24 & .43 & 0 & 1 \\
\hline Indicator: obese & 527 & .49 & .50 & 0 & 1 \\
\hline Indicator: No skills & 527 & .06 & .24 & 0 & 1 \\
\hline Indicator: Low skilled & 527 & 12 & .32 & 0 & 1 \\
\hline $\begin{array}{l}\text { Indicator: less than high school } \\
\text { education }\end{array}$ & 527 & .25 & .43 & 0 & 1 \\
\hline $\begin{array}{l}\text { Indicator: more than a high school } \\
\text { education }\end{array}$ & 527 & .34 & .47 & 0 & 1 \\
\hline Number of caregiven children & 527 & 2.02 & 1.2 & 0 & 7 \\
\hline Number of children aged 0-2 cared for & 527 & .23 & .48 & 0 & 3 \\
\hline Indicator: child has health problem & 527 & .18 & .39 & 0 & 1 \\
\hline Indicator: currently married / cohabiting & 527 & .51 & .50 & 0 & 1 \\
\hline Indicator: never married & 527 & .36 & .48 & 0 & 1 \\
\hline Indicator: pregnant & 527 & .04 & .20 & 0 & 1 \\
\hline Indicator: age 18-24 & 527 & .11 & .31 & 0 & 1 \\
\hline Indicator: age 25-34 & 527 & .46 & .50 & 0 & 1 \\
\hline Indicator: age 35-44 & 527 & .35 & .48 & 0 & 1 \\
\hline Indicator: no car or no license & 527 & .21 & .41 & 0 & 1 \\
\hline Indicator: wave 3 data & 527 & .52 & .50 & 0 & 1 \\
\hline Indicator: criminal conviction & 527 & .07 & .25 & 0 & 1 \\
\hline Indicator: learning disability & 527 & .19 & .39 & 0 & 1 \\
\hline Indicator: probable major depression & 527 & 19 & .39 & 0 & 1 \\
\hline Indicator: any mental health barrier & 527 & 37 & .48 & 0 & 1 \\
\hline Indicator: health is fair or poor & 527 & .36 & .48 & 0 & 1 \\
\hline $\begin{array}{l}\text { Physical limitation scale (higher is } \\
\text { better) }\end{array}$ & 527 & 20.2 & 4.35 & 8 & 24 \\
\hline
\end{tabular}

Note: measures of weight and height have been corrected for reporting error; see the Appendix. 
Table 1B: Summary Statistics for African-American Non-Hispanic Sample

\begin{tabular}{|c|c|c|c|c|c|}
\hline Variable & \multicolumn{5}{|c|}{ Summary Statistics } \\
\hline & $\mathbf{N}$ & Mean & S.D. & Min & Max \\
\hline Indicator: not working & 651 & .37 & .48 & 0 & 1 \\
\hline Indicator: working full time & 651 & .47 & .50 & 0 & 1 \\
\hline Hours worked & 651 & 25.16 & 21.89 & 0 & 95 \\
\hline Own earnings last month (2001 \$) & 651 & 753.09 & 751.53 & 0 & 5600 \\
\hline $\begin{array}{l}\text { Percent of months worked since last } \\
\text { interview }\end{array}$ & 651 & .72 & .36 & 0 & 1 \\
\hline $\begin{array}{l}\text { Percent of months of wage reliance since } \\
\text { last interview }\end{array}$ & 651 & .53 & .40 & 0 & 1 \\
\hline $\begin{array}{l}\text { Percent of months on welfare since last } \\
\text { interview }\end{array}$ & 651 & .35 & .39 & 0 & 1 \\
\hline $\begin{array}{l}\text { Percent of months of welfare reliance } \\
\text { since last interview }\end{array}$ & 651 & .16 & .29 & 0 & 1 \\
\hline $\begin{array}{l}\text { Indicator: reports discrimination on basis } \\
\text { of weight at current / most recent job }\end{array}$ & 523 & .01 & .12 & 0 & 1 \\
\hline Weight in pounds & 651 & 185.29 & 43.55 & 75.33 & 348.83 \\
\hline Height in inches & 651 & 63.70 & 2.45 & 57.32 & 71.14 \\
\hline Body Mass Index & 651 & 32.16 & 7.65 & 12.84 & 61.32 \\
\hline Indicator: underweight & 651 & .00 & .06 & 0 & 1 \\
\hline Indicator: healthy weight & 651 & .15 & .36 & 0 & 1 \\
\hline Indicator: overweight & 651 & .28 & .45 & 0 & 1 \\
\hline Indicator: obese & 651 & .56 & .50 & 0 & 1 \\
\hline Indicator: No skills & 651 & .08 & .26 & 0 & 1 \\
\hline Indicator: Low skilled & 651 & .16 & .37 & 0 & 1 \\
\hline Indicator: less than high school education & 651 & .27 & .45 & 0 & 1 \\
\hline $\begin{array}{l}\text { Indicator: more than a high school } \\
\text { education }\end{array}$ & 651 & .36 & .48 & 0 & 1 \\
\hline Number of caregiven children & 651 & 2.38 & 1.49 & 0 & 9 \\
\hline Number of children aged 0-2 cared for & 651 & .26 & .51 & 0 & 3 \\
\hline Indicator: child has health problem & 651 & .12 & .32 & 0 & 1 \\
\hline Indicator: currently married / cohabiting & 651 & .28 & .45 & 0 & 1 \\
\hline Indicator: never married & 651 & .68 & .47 & 0 & 1 \\
\hline Indicator: pregnant & 651 & .05 & .22 & 0 & 1 \\
\hline Indicator: age 18-24 & 651 & .13 & .34 & 0 & 1 \\
\hline Indicator: age 25-34 & 651 & .51 & .50 & 0 & 1 \\
\hline Indicator: age 35-44 & 651 & .29 & .46 & 0 & 1 \\
\hline Indicator: no car or no license & 651 & .34 & .48 & 0 & 1 \\
\hline Indicator: wave 3 data & 651 & .53 & .50 & 0 & 1 \\
\hline Indicator: criminal conviction & 651 & .04 & .20 & 0 & 1 \\
\hline Indicator: learning disability & 651 & .13 & .33 & 0 & 1 \\
\hline Indicator: probable major depression & 651 & 18 & 38 & 0 & 1 \\
\hline Indicator: any mental health barrier & 651 & .31 & .47 & 0 & 1 \\
\hline Indicator: health is fair or poor & 651 & .30 & .46 & 0 & 1 \\
\hline Physical limitation scale (higher is better) & 651 & 20.4 & 4.48 & 8 & 24 \\
\hline
\end{tabular}

Note: measures of weight and height have been corrected for reporting error; see the Appendix. 
Table 2

Outcome: Indicator for Not Currently Working Logit Coefficients, (t statistics), and [elasticities]

\begin{tabular}{|c|c|c|}
\hline $\begin{array}{c}\text { Weight } \\
\text { Variable }\end{array}$ & $\begin{array}{c}\text { White } \\
\text { Non-Hispanics }\end{array}$ & $\begin{array}{c}\text { African-American } \\
\text { Non-Hispanics }\end{array}$ \\
\hline $\begin{array}{l}\text { Weight in } \\
\text { Pounds }\end{array}$ & $\begin{array}{c}.0079 \\
(1.84) \\
{[1.208]}\end{array}$ & $\begin{array}{c}-.0012 \\
(-.36) \\
{[-.154]}\end{array}$ \\
\hline $\begin{array}{l}\text { Body Mass } \\
\text { Index }\end{array}$ & $\begin{array}{c}.0411 \\
(1.69) \\
{[1.094]}\end{array}$ & $\begin{array}{c}-.0062 \\
(-.34) \\
{[-.140]}\end{array}$ \\
\hline $\begin{array}{l}\text { Mean of } \\
\text { Dependent } \\
\text { Variable }\end{array}$ & .33 & .37 \\
\hline \# Observations & 527 & 651 \\
\hline
\end{tabular}

Notes:

1) Data: pooled data from waves 3 and 4 of the Women's Employment Study.

2) Standard errors are cluster-corrected by individual.

3) Other regressors in each regression: the number of children the respondent cares for, the number of children between the ages of 0 and 2 that the respondent cares for, and indicator variables for no job market skills, low job market skills, less than a high school education, more than a high school education, one of the respondent's children has a physical or mental health problem, respondent is currently cohabitating with a husband or boyfriend, never married, age, the respondent is unable to drive because they either have no car or no license, wave 3 data, respondent has a conviction for other than a traffic offense, and respondent has a learning disability. When weight in pounds is the weight measure, we also control for height in inches. 


\section{Table 3}

Outcome: Indicator for Full-Time Employment Logit Coefficients, (t statistics), and [elasticities]

\begin{tabular}{|c|c|c|c|c|}
\hline $\begin{array}{l}\text { Weight } \\
\text { Variable }\end{array}$ & \multicolumn{2}{|c|}{$\begin{array}{c}\text { White } \\
\text { Non-Hispanics }\end{array}$} & \multicolumn{2}{|c|}{$\begin{array}{c}\text { African-American } \\
\text { Non-Hispanics }\end{array}$} \\
\hline $\begin{array}{l}\text { Weight in } \\
\text { Pounds }\end{array}$ & $\begin{array}{l}-.0081 \\
(-2.16) \\
{[-.889]}\end{array}$ & & $\begin{array}{c}-.0018 \\
(-.61) \\
{[-.174]}\end{array}$ & \\
\hline $\begin{array}{l}\text { Body Mass } \\
\text { Index }\end{array}$ & & $\begin{array}{l}-.0456 \\
(-2.10) \\
{[-.879]}\end{array}$ & & $\begin{array}{c}-.0109 \\
(-.67) \\
{[-.187]}\end{array}$ \\
\hline $\begin{array}{l}\text { Mean of } \\
\text { Dependent } \\
\text { Variable }\end{array}$ & .42 & .42 & .47 & .47 \\
\hline \# Observations & 527 & 527 & 651 & 651 \\
\hline
\end{tabular}

Notes:

1) Data: pooled data from waves 3 and 4 of the Women's Employment Study.

2) Standard errors are cluster-corrected by individual.

3) Other regressors in each regression: the number of children the respondent cares for, the number of children between the ages of 0 and 2 that the respondent cares for, and indicator variables for no job market skills, low job market skills, less than a high school education, more than a high school education, one of the respondent's children has a physical or mental health problem, respondent is currently cohabitating with a husband or boyfriend, never married, age, the respondent is unable to drive because they either have no car or no license, wave 3 data, respondent has a conviction for other than a traffic offense, and respondent has a learning disability. When weight in pounds is the weight measure, we also control for height in inches. 
Table 4

Outcome: Natural Logarithm of Hours Worked Per Week

OLS Coefficients, (t statistics), and [elasticities]

\begin{tabular}{|c|c|c|c|c|}
\hline $\begin{array}{c}\text { Weight } \\
\text { Variable }\end{array}$ & \multicolumn{2}{|c|}{$\begin{array}{c}\text { White } \\
\text { Non-Hispanics }\end{array}$} & \multicolumn{2}{|c|}{$\begin{array}{c}\text { African-American } \\
\text { Non-Hispanics }\end{array}$} \\
\hline $\begin{array}{l}\text { Weight in } \\
\text { Pounds }\end{array}$ & $\begin{array}{c}-.003 \\
(-1.91) \\
{[-.545]}\end{array}$ & & $\begin{array}{c}.0006 \\
(.33) \\
{[.104]}\end{array}$ & \\
\hline $\begin{array}{l}\text { Body Mass } \\
\text { Index }\end{array}$ & & $\begin{array}{l}-.0164 \\
(-1.80) \\
{[-.514]}\end{array}$ & & $\begin{array}{l}.0027 \\
(.28) \\
{[.088]}\end{array}$ \\
\hline $\begin{array}{l}\text { Mean of } \\
\text { Untransformed } \\
\text { Dependent } \\
\text { Variable }\end{array}$ & 25.16 & 25.16 & 24.59 & 24.59 \\
\hline $\begin{array}{l}\text { Mean of } \\
\text { Transformed } \\
\text { Dependent } \\
\text { Variable }\end{array}$ & 2.36 & 2.36 & 2.30 & 2.30 \\
\hline $\begin{array}{l}\text { \# Observations } \\
\text { R-squared }\end{array}$ & $\begin{array}{l}527 \\
.17\end{array}$ & $\begin{array}{l}527 \\
.17\end{array}$ & $\begin{array}{l}651 \\
.13\end{array}$ & $\begin{array}{l}651 \\
.13\end{array}$ \\
\hline
\end{tabular}

Notes:

1) Data: pooled data from waves 3 and 4 of the Women's Employment Study.

2) Standard errors are cluster-corrected by individual.

3) Other regressors in each regression: the number of children the respondent cares for, the number of children between the ages of 0 and 2 that the respondent cares for, and indicator variables for no job market skills, low job market skills, less than a high school education, more than a high school education, one of the respondent's children has a physical or mental health problem, respondent is currently cohabitating with a husband or boyfriend, never married, age, the respondent is unable to drive because they either have no car or no license, wave 3 data, respondent has a conviction for other than a traffic offense, and respondent has a learning disability. When weight in pounds is the weight measure, we also control for height in inches. 
Table 5

Outcome: Percent of Months Worked

Since Last Interview (Logit Transformed)

OLS Coefficients, (t statistics), and [elasticities]

\begin{tabular}{|c|c|c|c|c|}
\hline $\begin{array}{c}\text { Weight } \\
\text { Variable }\end{array}$ & \multicolumn{2}{|c|}{$\begin{array}{c}\text { White } \\
\text { Non-Hispanics }\end{array}$} & \multicolumn{2}{|c|}{$\begin{array}{c}\text { African-American } \\
\text { Non-Hispanics }\end{array}$} \\
\hline $\begin{array}{l}\text { Weight in } \\
\text { Pounds }\end{array}$ & $\begin{array}{l}-.0094 \\
(-2.14) \\
{[-.510]}\end{array}$ & & $\begin{array}{c}-.0028 \\
(-.59) \\
{[-.144]}\end{array}$ & \\
\hline $\begin{array}{l}\text { Body Mass } \\
\text { Index }\end{array}$ & & $\begin{array}{l}-.0530 \\
(-2.08) \\
{[-.489]}\end{array}$ & & $\begin{array}{c}-.0148 \\
(-.56) \\
{[-.133]}\end{array}$ \\
\hline $\begin{array}{l}\text { Mean of } \\
\text { Untransformed } \\
\text { Dependent } \\
\text { Variable }\end{array}$ & .70 & .70 & .72 & .72 \\
\hline $\begin{array}{l}\text { Mean of } \\
\text { Transformed } \\
\text { Dependent } \\
\text { Variable }\end{array}$ & 2.53 & 2.53 & 2.66 & 2.66 \\
\hline \# Observations & 527 & 527 & 651 & 651 \\
\hline R-squared & .17 & .17 & .16 & .16 \\
\hline
\end{tabular}

Notes:

1) Data: pooled data from waves 3 and 4 of the Women's Employment Study.

2) Standard errors are cluster-corrected by individual.

3) Other regressors in each regression: the number of children the respondent cares for, the number of children between the ages of 0 and 2 that the respondent cares for, and indicator variables for no job market skills, low job market skills, less than a high school education, more than a high school education, one of the respondent's children has a physical or mental health problem, respondent is currently cohabitating with a husband or boyfriend, never married, age, the respondent is unable to drive because they either have no car or no license, wave 3 data, respondent has a conviction for other than a traffic offense, and respondent has a learning disability. When weight in pounds is the weight measure, we also control for height in inches. 


\section{Table 6}

Outcome: Percent of Months on Welfare

Since Last Interview (Logit Transformed)

OLS Coefficients, (t statistics), and [elasticities]

\begin{tabular}{|c|c|c|c|c|}
\hline $\begin{array}{l}\text { Weight } \\
\text { Variable }\end{array}$ & \multicolumn{2}{|c|}{$\begin{array}{c}\text { White } \\
\text { Non-Hispanics }\end{array}$} & \multicolumn{2}{|c|}{$\begin{array}{c}\text { African-American } \\
\text { Non-Hispanics }\end{array}$} \\
\hline $\begin{array}{l}\text { Weight in } \\
\text { Pounds }\end{array}$ & $\begin{array}{c}.0121 \\
(2.66) \\
{[1.596]}\end{array}$ & & $\begin{array}{c}.0091 \\
(1.93) \\
{[1.092]}\end{array}$ & \\
\hline $\begin{array}{l}\text { Body Mass } \\
\text { Index }\end{array}$ & & $\begin{array}{c}.0663 \\
(2.51) \\
{[1.518]}\end{array}$ & & $\begin{array}{l}.0561 \\
(2.11) \\
{[1.174]}\end{array}$ \\
\hline $\begin{array}{l}\text { Mean of } \\
\text { Untransformed } \\
\text { Dependent } \\
\text { Variable }\end{array}$ & .27 & .27 & .35 & .35 \\
\hline $\begin{array}{l}\text { Mean of } \\
\text { Transformed } \\
\text { Dependent } \\
\text { Variable } \\
\text { \# Observations }\end{array}$ & -3.13 & -3.13 & -1.87 & -1.87 \\
\hline R-squared & .22 & .21 & .21 & .21 \\
\hline
\end{tabular}

Notes:

1) Data: pooled data from waves 3 and 4 of the Women's Employment Study.

2) Standard errors are cluster-corrected by individual.

3) Other regressors in each regression: the number of children the respondent cares for, the number of children between the ages of 0 and 2 that the respondent cares for, and indicator variables for no job market skills, low job market skills, less than a high school education, more than a high school education, one of the respondent's children has a physical or mental health problem, respondent is currently cohabitating with a husband or boyfriend, never married, age, the respondent is unable to drive because they either have no car or no license, wave 3 data, respondent has a conviction for other than a traffic offense, and respondent has a learning disability. When weight in pounds is the weight measure, we also control for height in inches. 


\section{Table 7}

\section{Outcome: Natural Logarithm of Own Earnings Last Month in 2001 Dollars OLS Coefficients, (t statistics), and [elasticities]}

\begin{tabular}{|c|c|c|c|c|}
\hline $\begin{array}{c}\text { Weight } \\
\text { Variable }\end{array}$ & \multicolumn{2}{|c|}{$\begin{array}{c}\text { White } \\
\text { Non-Hispanics }\end{array}$} & \multicolumn{2}{|c|}{$\begin{array}{c}\text { African-American } \\
\text { Non-Hispanics }\end{array}$} \\
\hline $\begin{array}{l}\text { Weight in } \\
\text { Pounds }\end{array}$ & $\begin{array}{c}-.0055 \\
(-1.97) \\
{[-1.003]}\end{array}$ & & $\begin{array}{c}-.0023 \\
(-.73) \\
{[-.432]}\end{array}$ & \\
\hline $\begin{array}{l}\text { Body Mass } \\
\text { Index }\end{array}$ & & $\begin{array}{l}-.0281 \\
(-1.73) \\
{[-.883]}\end{array}$ & & $\begin{array}{c}-.0139 \\
(-.77) \\
{[-.446]}\end{array}$ \\
\hline $\begin{array}{l}\text { Mean of } \\
\text { Untransformed } \\
\text { Dependent } \\
\text { Variable }\end{array}$ & 768.75 & 768.75 & 753.09 & 753.09 \\
\hline $\begin{array}{l}\text { Mean of } \\
\text { Transformed } \\
\text { Dependent } \\
\text { Variable }\end{array}$ & 4.86 & 4.86 & 4.68 & 4.68 \\
\hline \# Observations & 527 & 527 & 651 & 651 \\
\hline R-squared & .20 & .20 & .12 & .12 \\
\hline
\end{tabular}

Notes:

1) Data: pooled data from waves 3 and 4 of the Women's Employment Study.

2) Standard errors are cluster-corrected by individual.

3) Other regressors in each regression: the number of children the respondent cares for, the number of children between the ages of 0 and 2 that the respondent cares for, and indicator variables for no job market skills, low job market skills, less than a high school education, more than a high school education, one of the respondent's children has a physical or mental health problem, respondent is currently cohabitating with a husband or boyfriend, never married, age, the respondent is unable to drive because they either have no car or no license, wave 3 data, respondent has a conviction for other than a traffic offense, and respondent has a learning disability. When weight in pounds is the weight measure, we also control for height in inches. 
Table 8

Elasticity of Each Outcome With Respect to Weight in Pounds and BMI

\begin{tabular}{|c|l|c|c|c|c|}
\hline \multirow{2}{*}{ Row } & \multicolumn{1}{|c|}{ Outcome } & \multicolumn{2}{|c|}{$\begin{array}{c}\text { White } \\
\text { Non-Hispanics }\end{array}$} & \multicolumn{2}{c|}{$\begin{array}{c}\text { African American } \\
\text { Non-Hispanics }\end{array}$} \\
\cline { 3 - 6 } & & $\begin{array}{c}\text { Weight in } \\
\text { Pounds }\end{array}$ & BMI & $\begin{array}{c}\text { Weight in } \\
\text { Pounds }\end{array}$ & BMI \\
\hline 1 & $\begin{array}{l}\text { Indicator: not } \\
\text { working }\end{array}$ & 1.208 & 1.094 & -.154 & -.140 \\
\hline 2 & $\begin{array}{l}\text { Indicator: working } \\
\text { full time }\end{array}$ & -.889 & -.879 & -.174 & -.187 \\
\hline 3 & Hours worked & -.545 & -.514 & .104 & .088 \\
\hline 4 & $\begin{array}{l}\text { Percent of months } \\
\text { worked since last } \\
\text { interview }\end{array}$ & -.510 & -.498 & -.144 & -.133 \\
\hline 5 & $\begin{array}{l}\text { Percent of months } \\
\text { on welfare since } \\
\text { last interview }\end{array}$ & 1.596 & 1.518 & 1.092 & 1.174 \\
\hline 6 & $\begin{array}{l}\text { Own earnings last } \\
\text { month }\end{array}$ & -1.003 & -.883 & -.432 & -.446 \\
\hline
\end{tabular}

Notes:

1) In rows 1 and 2, which reflect logit regressions, the elasticity of outcomes with respect to weight is calculated as: $\varepsilon=\left[1-\Lambda\left(X^{\prime} \beta\right)\right]^{*} \bar{W} \beta_{W}$ where $X$ is the vector of regressors, $\beta$ is the vector of coefficients, $\bar{W}$ is the average weight in the sample, and $\beta_{W}$ is the coefficient on weight.

2) In rows 3 and 6 , which reflect regressions in which the dependent variable has been transformed by the natural logarithm, the elasticity is calculated as $\varepsilon=\bar{W} \beta_{W}$.

3) In rows 4 and 5 , which reflect regressions in which the dependent variable is a percentage that has been logit transformed, the elasticity of outcomes with respect to weight is calculated as: $\varepsilon=(1-\bar{Y}) \bar{W} \beta_{W}$ where $\bar{Y}$ is the average outcome of interest in the sample, $\bar{W}$ is the average weight in the sample, and $\beta_{W}$ is the coefficient on weight. 


\section{Appendix Table 1 \\ Means of Weight and Height Variables \\ Self-Reported and Corrected for Reporting Error \\ For Subset of WES Respondents That Were Weighed and Measured}

\begin{tabular}{|c|c|c|c|c|}
\hline & \multicolumn{2}{|c|}{$\begin{array}{c}\text { White } \\
\text { Non-Hispanics }\end{array}$} & \multicolumn{2}{|c|}{$\begin{array}{c}\text { African-American } \\
\text { Non-Hispanics }\end{array}$} \\
\hline & Self-Reported & Corrected & Self-Reported & Corrected \\
\hline Weight (pounds) & 172.22 & 184.51 & 182.20 & 190.58 \\
\hline Height (inches) & 64.2 & 63.53 & 64.40 & 63.71 \\
\hline Body Mass Index & 29.41 & 32.14 & 30.97 & 33.07 \\
\hline Percent Underweight & .04 & .02 & .03 & .00 \\
\hline Percent Healthy Weight & .27 & .17 & .22 & .10 \\
\hline Percent Overweight & .27 & .26 & .29 & .29 \\
\hline Percent Obese & .41 & .54 & .46 & .60 \\
\hline
\end{tabular}

Notes:

1) Respondents report their height and weight; self-reported BMI and clinical weight classifications are derived from those reports.

2) Correction method described in Appendix 1.

3) This sample consists of only the subset of WES respondents whose weight and height were measured. In contrast, the summary statistics in Tables $1 \mathrm{~A}$ and $1 \mathrm{~B}$ reflect the entire sample of WES respondents. 